\title{
Valuation of Shares and their Fair Value of the Companies Listed on the Wig-Ukraine Quoted on the Warsaw Stock Exchange in Poland within 2011-2015
}

\author{
Rafal Parvi \\ School of Banking in Wroclaw \\ Street Fabryczna 29-31, 53-609 Wroclaw, Poland
}

\begin{abstract}
This paper examines share price of the companies listed on the WIG-Ukraine and their fair value between 2011-2015. Data from Q4 2013 to Q2 2014 was collected from the Stooq.pl (Polish portal of shares). Two hypotheses are tested: (1) value of the shares based on the market price; (2) value of the shares as the fair value of shares. In this paper, the WIG-UKRAINA stock exchange sector companies, which oppose a bad economic situation in Ukraine caused by military actions on its territory, were analysed. These companies were subject to detailed research in order to demonstrate that they have the potential to act on the free market and that they do not lose their financial liquidity. In addition, their fair value was shown, because the current economic and market situation in Ukraine completely deprived it of this value.
\end{abstract}

Keywords: Stock exchange, Share valuation, Fair value, Companies, Market shares, Market situations

\section{Introduction}

Share valuation is one of the most complex processes on financial markets since the value of shares does not depend only on demand and supply on the market, but also on many factors that determine its price, starting from business valuation by using different methods in the given time to the presentation of mechanisms changing the value of shares in a manner either increasing or decreasing its value. For this reason, it is so important to value shares and determine its fair value in a manner that is objective and independent of speculative values that distort share prices and hence of the value of a WSE-listed company, which research conducted on the WIG-Ukraine index applies to. The value of companies listed on this index should be analyzed in terms of estimating their fair value, since presently their value should arouse significant controversies, especially at good operation of companies.

\section{Ukrainian Economy}

A fall in GDP of 6\% in Ukraine would be a good result, because the economic situation has dramatically deteriorated due to the war in Eastern Ukraine. Such an index is consistent with the forecast of the International Monetary Fund, which estimates this year's expected reduction of GDP to 6.5\%. However, according to the Ukraine's central bank, it will rise to $10 \%$. As Szlapak emphasised, in 2015, Ukraine can gain the economic growth of $2 \%$, if the parliament approves the planned tax reform. Fiscal changes will be also introduced, and the reform will include the income tax and tax on corporate profits, as well as social security contributions.

Within the framework of the reform, six income groups of both natural and legal persons, singled out for the fiscal purposes, is to be replaced with only three, and the tax rate for the lowest group will be reduced by half.

However, it should be taken into account that the Ukrainian hryvnia loses value so much that in terms of the minimum wage converted into dollars, Ukraine fell below the level of poor countries of Africa and Asia, which was calculated by

International Journal of Operations Management, vol. 1, issue 3, pp. 17-24, April 2021 
the Ukraine television. The Ukrainian minimum wage is UAH 1218, and currently it is the value of 42.9 dollars, while, e.g. in Ghana, Bangladesh, or Zambia, it is 46.6 dollars.

Since the downfall of the President Viktor Yanukovych, hryvnia has lost more than $70 \%$ in value. Ukraine is currently being devastated by the conflict with pro-Russian separatists in the east of the country. A big problem is also the widespread corruption and sluggish pace of introducing necessary reforms.

Poland, which has 25-year experience in the economic transformation, offers Ukraine assistance in management, and can pass on this know-how to Ukraine, which is at the beginning of this road. Poland may also economically advise it in terms of reforms. However, the Ukrainians will have to give only the will and desire to take advantage of our experience, which was struggled with success and sometimes mistakes.

\section{Fair Value of Listed Companies}

Share price of the companies listed on the Stock Exchange should reflect also their fair value (Pierce, 2004, pp. 124145). The fair value can be defined in several ways. In view of the foregoing, the fair value is a value used repeatedly in accounting, and thus in Article 28 (6) of the Accounting Act of 29.09.1994 as "the amount for which a given asset component could be exchanged, and the liability could be paid on market transaction terms between interested and wellinformed, unrelated parties.

In view of whether the price of shares that are quoted on the stock exchange corresponds to their fair value, should be found in the value alone, since, after all, the values may be diverse, like the value of a similar company, producing similar goods and operating in the same industry, will also be diverse for various reasons.

The subject of trade covers minority shares, and the main market participants are retail investors or minority institutional investors, thus the price of shares should reflect the fair value characterizing the liquid minority interest (Borowski, 2013).

The value presented in this way seems righteous, which is confirmed by the premium paid by the investors who announce calls for subscription for shares and plan in this way the purchase of the controlling interest. Then the premium reflects the difference between the level of liquid minority interest and the level of controlling interest. Sometimes the level takes into account benefits resulting from synergy. An investor purchasing the controlling interest in this way receives premiums that appear after taking over control of a company, in the form of funds, business management and making a number of strategic decisions.

The fair value of the share price should be determined in accordance with the idea of capital market, namely the market participants should have equal access to data, information and all messages concerning a given company. However, the investors are divided into three groups:

People with access to the most closely guarded information that affects the price and the business value, namely those can the company's management board or shareholders,

Institutional investors with blocks of shares with simultaneous access to the company's management board,

Individual investors who have access to public information.

At this point, there should be no differences in particular groups, at least officially, however, it happens that a group that is closest to the company has information which can obviously change its value overnight or distort its value artificially, e.g. other data or informal data, and even fictitious data. Worldwide we can also appreciate companies that treat individual investors seriously, namely provide them data concerning a company and treat them as equal and as strategic investors, with a large impact on a company in the present and in the future. Transactions that are concluded on the Warsaw Stock Exchange relate to transactions between interested parties, namely a purchase or sale order should be submitted. Sometimes there are cases of wrongly submitted orders, but these are marginal orders that do not have a large impact on the transactions conducted on the Warsaw Stock Exchange. Share liquidity is understood as a percentage quantity of shares 
in a company that are in the possession of minority shareholders. This is, at the same time, free float and the face value of such shares and the value of average daily trade in shares in a given company (Kufel, 1992).

Thus, we may presume that if during a day a large trade in shares takes place and a greater part of shares remains in the hands of minor shareholders, the share price reflects their fair value. We cannot agree with the fact that at small or minimum trade the value of shares is reduced to its daily minimum and it would be its fair value. Then it is only a change in the share price to a lower one and it does not indicate its fair value, as the trade alone suggests that this is only a pure coincidence. Such an impact can be exerted by large shareholders, as they can, by using one block, decrease the share value, preventing smaller players from raising the price for one reason: the capital of smaller shareholders does not enable them to raise the share price (Veale, 2001; Frąckowiak, 1998).

There is one premise more to determine the fair value of share price. The investors are fond of investing in shares, namely they buy them as in the past they managed to earn on them and they feel that presently the share price is ideal and reflects their fair value and will enable them to obtain fair dividend in the future. Such a purchase or sale of shares can largely overestimate or underestimate the share value of a quoted company. Here the IT industry may serve as an example, namely shares in technological companies at the beginning of the new millennium, when shares in these companies were being purchased without any analysis in technical terms, but looking at their name and value, which was increasing overnight. In view of the foregoing, this led to excessively high business value above its fair value (Thompson, 2008). The share price should thus reflect the fair value of a company listed on the Warsaw Stock Exchange. For the value of these companies be fair, the market must make available to all investors information regarding companies listed on the Warsaw Stock Exchange. The shareholders should be treated equally; therefore, we cannot distinguish majority shareholders as those who should have information unavailable for minority shareholders. First of all, shares should be liquid securities, therefore they should be in free float and have real-time transferability, namely at any moment and at any time during the office hours of the Warsaw Stock Exchange on a business day (The analysis of 233 recommendations or analytical reports issued by broker's offices in the period from January 2014 to January 2015, concerning 41 companies comprising the WIG20 and mWIG40 indexes of the Warsaw Stock Exchange).

\section{Wig-Ukraine and Shares in the Companies Listed on it}

The WIG-Ukraine index groups only shares in Ukrainian companies listed on the Main Market of the Warsaw Stock Exchange. This index enables investors to estimate investment demand in a given sector but only for the Ukrainian companies listed on the Warsaw Stock Exchange, and is the basis for assessment of investment results. This is a total return index, which takes into account dividend and preemptive rights and free float. The index has been calculated since 31.12.2010 and its initial value was 1000 points. However, the index value as of 04.03 .2015 is 278.79 points, namely it is overvalued over $70 \%$ in relation to the initial value, which shows its downward trend.

Value of the WIG-Ukraine index:

$$
\begin{gathered}
\mathrm{M}(\mathrm{t}) \\
\mathrm{WIG}(0) * \mathrm{~K}(\mathrm{t})
\end{gathered}
$$

$M(t)$ - index portfolio capitalization at session $t$

$\mathrm{M}(0)$ - index portfolio capitalization on a base dayK (t)-index adjustment factor at session $\mathrm{t}$ 


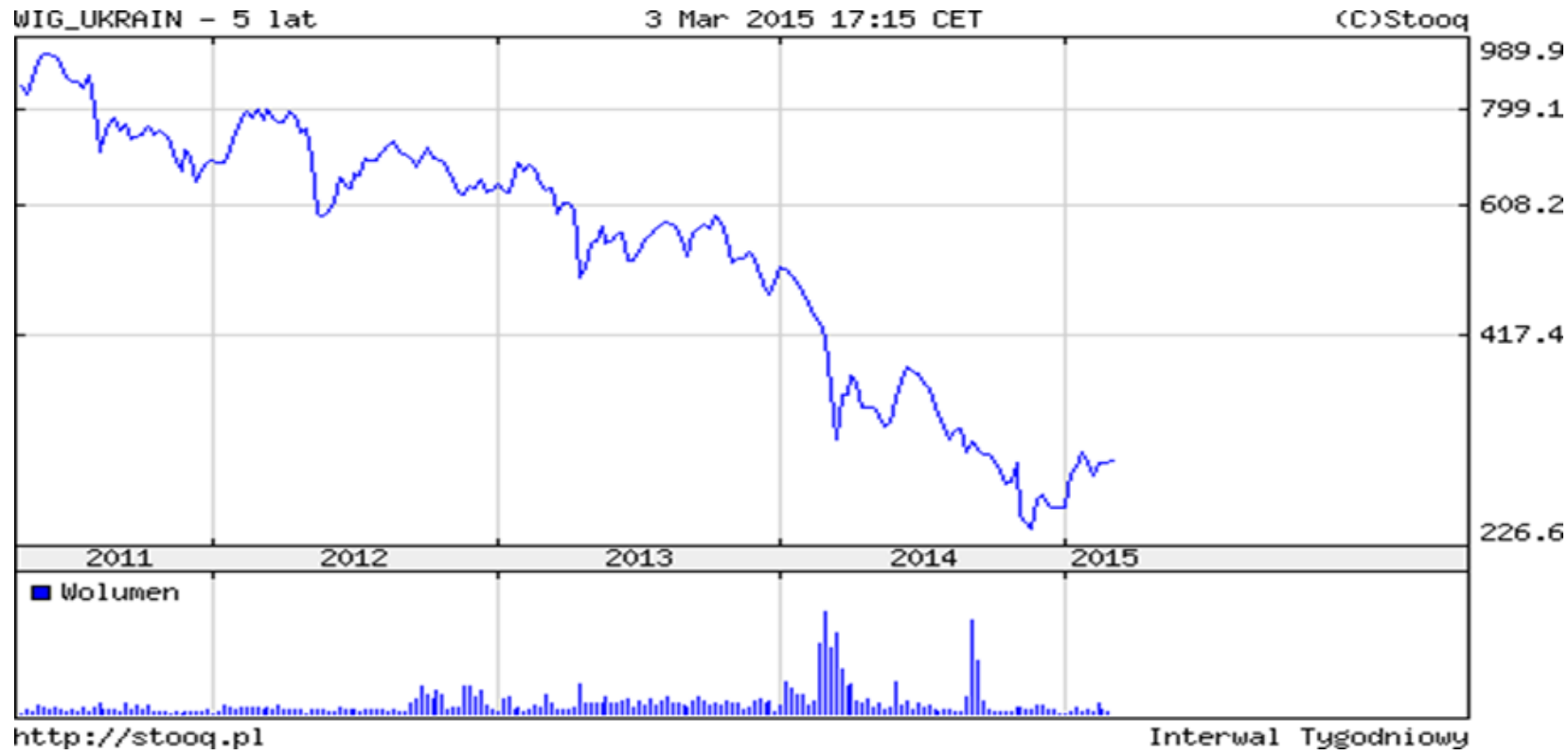

Figure 1: WIG-Ukraine index in the years $2011-2015$

Source: stooq.pl

The WIG-Ukraine, as the second national index calculated by the stock exchange, is an index showing very expressively operations of the Ukrainian companies. It consists of the companies listed on the Warsaw Stock Exchange seated in Ukraine or whose operations are conducted predominantly in this country. However, the WIG-Ukraine as a total return index includes both prices of shares contained in it and earnings from dividends and preemptive rights, which should be expressed as the fair value, however, it is not the case (Jajuga K, Jajuga T., 1996).

The chart WIG-Ukraine P/E presents the present value as of 04.03.2015 of 3.30, which proves that the total price to earnings ratio shows upward trend and it should come back to 12, as those companies have high financial potential, are investing their funds well and have been significantly undervalued and their fair value has been underestimated.

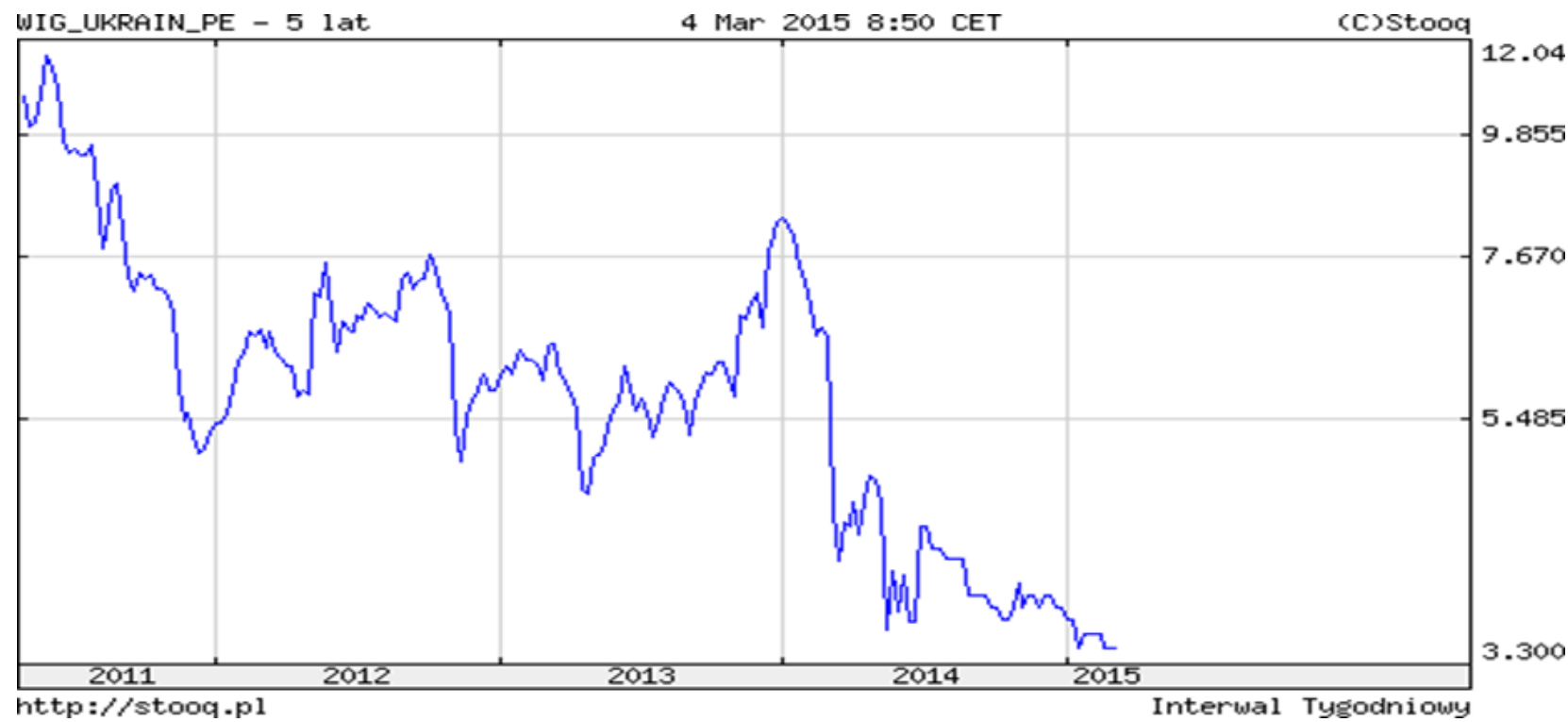

Figure 2: WIG-Ukraine P/E in the years 2011 - 2015

Source: stooq.pl

The companies listed on the WIG-Ukraine index have good financial standing:

a) COALENERG - the main object of operations of the Group is extraction, enrichment and sale of steam coal and coke. CoalEnergy is the third, in respect of the volume of owned reserves, according to the situation at the end of 2010, private 
coal producer in Ukraine and the seventh, in respect of extraction, private coal producer in this country, taking into account the results of companies for 2010.

b) ASTARTA HOLDING NV - agricultural and industrial holding, one of leaders of the Ukrainian sugar sector. The company has been focusing its operations on the production and sale of sugar produced from beetroot and on the production and sale of cereals, which results from the need to use crop rotation in the beetroot cultivation.

c) KERNEL HOLDING SA - conducts integrated operations in the sector of bottled edible oils and in agribusiness, with the scope including all production stages, from cultivation of agricultural products to delivery of the final product to consumer. KERNEL HOLDING is a holding company registered in Luxembourg, whose main property are shares in production companies.

d) IMCOMPANY - company from the agricultural sector in central-north Ukraine. The operations of IMC are focused on the cultivation of cereals, oil plants and potatoes, and the Company is also one of the largest milk producers in Ukraine.

e) KSGAGRO - agricultural holding controlling the acreage with total area of about 33,700 hectares. The main tasks of the Group include the production of cereals such as corn, wheat, barley, rapeseed and soya bean, and the production of vegetables and the supply of food products to commercial chains.

f) KDM SHIPPING PUBLIC LTD - Ukrainian company operating in the transport navigation industry, focusing on a niche segment of the river and sea transport of dry bulk goods in the area of the Black Sea, the Sea of Azov and the Mediterranean Sea. The company provides also ship repair services, ship-building services, and operates river passenger carriages. The KDM Shipping Group has a fleet of eight bulk cargo ships to the river and sea transport of bulk cargo, with deadweight capacity of 25206 tons.

g) MILKILAND - leading manufacturer of dairy products, such as cheeses, yoghurts or butter, operating on one of the largest and most dynamically developing markets, in the Community of Independent States (CIS), mainly in Ukraine and Russia.

h) OVOSTAR UNION NV - the Group is one of leaders on the eggs and egg products market in Ukraine, specializing in the production of brand high-quality products. In 2010 the share of the Group on the egg market was $5.4 \%$ of the total quantity of produced eggs, and the share in the market of egg products was $38 \%$ of the total quantity of egg products.

The current price of shares of the companies listed on the WIG-Ukraine should reflect their business value and their fair value, however, bearing in mind their maximum value, we should note that for well prospering companies their current value differs strikingly from the average or maximum value that was determined during quotations over the last few years, as shown in Table 1 (1).

Table 1: Companies listed on the WIG-UKRAINE in Poland as of 04.03.2015

\begin{tabular}{|c|c|c|c|c|}
\hline Name & Average assessment & rating & $\begin{array}{c}\text { Current price } \\
\text { PLN }\end{array}$ & $\begin{array}{l}\text { Max price } \\
\text { PLN }\end{array}$ \\
\hline COALENERG & $4.5 / 5.0$ & CCC- & 0.64 & 28.68 \\
\hline $\begin{array}{l}\text { ASTARTA } \\
\text { Holding NV }\end{array}$ & $4.0 / 5.0$ & AAA & 25.50 & 102.62 \\
\hline $\begin{array}{l}\text { KERNEL } \\
\text { Holding SA }\end{array}$ & $3.5 / 5.0$ & $\mathrm{AA}+$ & 31.99 & 86.58 \\
\hline IMCOMPANY & $4.5 / 5.0$ & AA- & 5.90 & 17.36 \\
\hline KSGAGRO & $3.5 / 5.0$ & $\mathrm{BBB}$ & 1.08 & 28.08 \\
\hline $\begin{array}{l}\text { KDMSHIPPING } \\
\text { PUBLIC LTD }\end{array}$ & $4.0 / 5.0$ & AAA & 5.63 & 37.08 \\
\hline MILKILAND & $5.0 / 5.0$ & $\mathrm{~B}+$ & 3.61 & 49.26 \\
\hline $\begin{array}{l}\text { OVOSTAR } \\
\text { UNION NV }\end{array}$ & $4.0 / 5.0$ & AAA & 69.90 & 130.57 \\
\hline
\end{tabular}

Source: by the author on the basis of the financial data of the WIG-Ukraine companies

The share price of some of them has been reduced by $98 \%$ (COALENERG) and of some by less than $60 \%$ (KERNEL HOLDING SA), which proves their diverse structure and diverse financial possibilities. With good financial data and generating earnings per share, the companies should resist crisis and stagnation prevailing currently on the world markets. However, it is unjust to quote rating for some companies in a manner showing their weakness, since those companies 
generate profit and are capable of surviving on the market and maintaining financial liquidity, which is proved by the financial results in tables 2 and 3. COALENERG may serve as an example.

Table 2 contains the most important ratios that show financial standing of the WIG-Ukraine companies. EBITDA per share is interesting, as it presents operating profit plus depreciation, which shows more effectively the companies with large fixed assets which require a very high capital expenditures characterized by a long period of return. In view of the above, EBITDA is a better ratio than EBIT, as it shows a better image of financial standing of an analyzed company (Parvi R., 2014, 33-36; Parvi R., 2014, pp. 52-60; Copeland, 1997, pp. 65-69).

In view of the so conducted analysis, we can clearly see that only five companies had problem with generating operating profit per share in the 2nd quarter of 2014: COALENERG, ASTARTA, KSGAGRO, KDMSHIPNG and MILKILAND. The other 3 companies generated operating profit per share as presented in Table 2. Almost all companies (8 companies) reduced assets to equity ratio, which resulted in release of equity and larger investment possibilities. The exception is KSGAGRO, which has increased assets to equity ratio by about 5\%. All the companies have a positive value of book value per share.

Table 2: Technical assessment of companies listed on the WIG-UKRAINE as of 31.12.2015

\begin{tabular}{|c|c|c|c|c|}
\hline Name & $\begin{array}{l}\text { Net profit (net loss) } \\
\text { in thousands }\end{array}$ & $\begin{array}{l}\text { Sales per } \\
\text { share }\end{array}$ & $\begin{array}{l}\text { Book value per } \\
\text { share }\end{array}$ & $\begin{array}{l}\text { EBITDA per } \\
\text { share }\end{array}$ \\
\hline \multicolumn{5}{|l|}{ COALENERG } \\
\hline $\begin{array}{l}\text { IV } \quad \text { quarter } \\
2013\end{array}$ & $\begin{array}{l}\text { (EURO) } \\
-2660\end{array}$ & No data & No data & $\begin{array}{l}\text { (EURO) } \\
1274\end{array}$ \\
\hline $\begin{array}{l}\text { II quarter } \\
2014\end{array}$ & $\begin{array}{l}\text { (EURO) } \\
-4103\end{array}$ & No data & No data & $\begin{array}{c}\text { (EURO) } \\
-2237\end{array}$ \\
\hline \multicolumn{5}{|l|}{ ASTARTA } \\
\hline $\begin{array}{l}\text { IV quarter } \\
2013\end{array}$ & $\begin{array}{l}\text { (EURO) } \\
-44762\end{array}$ & $\begin{array}{l}\text { (EURO) } \\
-1.790\end{array}$ & $\begin{array}{l}\text { (EURO) } \\
10.562\end{array}$ & $\begin{array}{l}\text { (EURO) } \\
37033\end{array}$ \\
\hline $\begin{array}{l}\text { II quarter } \\
2014\end{array}$ & $\begin{array}{l}\text { (EURO) } \\
-24940\end{array}$ & $\begin{array}{l}\text { (EURO) } \\
-0.998\end{array}$ & $\begin{array}{l}\text { (EURO) } \\
10.182\end{array}$ & $\begin{array}{l}\text { (EURO) } \\
-9992\end{array}$ \\
\hline \multicolumn{5}{|l|}{ KERNEL } \\
\hline $\begin{array}{l}\text { IV quarter } \\
2013\end{array}$ & $\begin{array}{l}\text { (EURO) } \\
-9097\end{array}$ & $\begin{array}{l}\text { (EURO) } \\
-0.114\end{array}$ & $\begin{array}{l}\text { (EURO) } \\
16.212\end{array}$ & $\begin{array}{l}\text { (EURO) } \\
31190\end{array}$ \\
\hline $\begin{array}{l}\text { II quarter } \\
2014\end{array}$ & $\begin{array}{l}\text { (EURO) } \\
23422\end{array}$ & $\begin{array}{l}\text { (EURO) } \\
0.294\end{array}$ & $\begin{array}{l}\text { EURO) } \\
12.832\end{array}$ & $\begin{array}{l}\text { (EURO) } \\
80460\end{array}$ \\
\hline \multicolumn{5}{|l|}{ IMCOMPANY } \\
\hline $\begin{array}{l}\text { IV quarter } \\
2013\end{array}$ & $\begin{array}{l}\text { (EURO) } \\
-8847\end{array}$ & $\begin{array}{l}\text { (EURO) } \\
-0.283\end{array}$ & $\begin{array}{l}\text { (EURO) } \\
4.864\end{array}$ & $\begin{array}{l}\text { (EURO) } \\
-2307\end{array}$ \\
\hline $\begin{array}{l}\text { II quarter } \\
2014\end{array}$ & $\begin{array}{l}\text { (EURO) } \\
31768\end{array}$ & $\begin{array}{l}\text { (EURO) } \\
1.014\end{array}$ & $\begin{array}{l}\text { (EURO) } \\
2.939\end{array}$ & $\begin{array}{l}\text { (EURO) } \\
48697\end{array}$ \\
\hline \multicolumn{5}{|l|}{ KSGAGRO } \\
\hline $\begin{array}{l}\text { IV quarter } \\
2013\end{array}$ & $\begin{array}{l}\text { (EURO) } \\
-39795\end{array}$ & $\begin{array}{l}\text { (EURO) } \\
-2.666\end{array}$ & $\begin{array}{l}\text { (EURO) } \\
3.359\end{array}$ & $\begin{array}{l}\text { (EURO) } \\
-31039\end{array}$ \\
\hline $\begin{array}{l}\text { II } \quad \text { quarter } \\
2014\end{array}$ & $\begin{array}{l}\text { (EURO) } \\
-9449\end{array}$ & $\begin{array}{l}\text { (EURO) } \\
-0.633\end{array}$ & $\begin{array}{l}\text { (EURO) } \\
1.675\end{array}$ & $\begin{array}{l}\text { (EURO) } \\
391\end{array}$ \\
\hline \multicolumn{5}{|l|}{ KDMSHIPNG } \\
\hline $\begin{array}{l}\text { IV quarter } \\
2013\end{array}$ & $\begin{array}{l}\text { (USD) } \\
-1874\end{array}$ & $\begin{array}{l}\text { (USD) } \\
-0.257\end{array}$ & $\begin{array}{l}\text { (USD) } \\
0.190\end{array}$ & $\begin{array}{l}\text { (USD) } \\
-1713\end{array}$ \\
\hline $\begin{array}{l}\text { II quarter } \\
2014\end{array}$ & $\begin{array}{l}\text { (USD) } \\
-769\end{array}$ & $\begin{array}{l}\text { (USD) } \\
-0.105\end{array}$ & $\begin{array}{l}\text { (USD) } \\
7.708\end{array}$ & $\begin{array}{l}\text { (USD) } \\
-513\end{array}$ \\
\hline
\end{tabular}


Rafal Parvi

School of Banking in Wroclaw

Street Fabryczna 29-31, 53-609 Wroclaw, Poland

\begin{tabular}{|c|c|c|c|c|}
\hline $\begin{array}{l}\text { IV quarter } \\
2013\end{array}$ & $\begin{array}{l}\text { (EURO) } \\
525\end{array}$ & $\begin{array}{l}\text { (EURO) } \\
0.017\end{array}$ & $\begin{array}{l}\text { (EURO) } \\
5.451\end{array}$ & $\begin{array}{l}\text { (EURO) } \\
10222\end{array}$ \\
\hline $\begin{array}{l}\text { II } \quad \text { quarter } \\
2014\end{array}$ & $\begin{array}{l}\text { (EURO) } \\
-2287\end{array}$ & $\begin{array}{l}\text { (EURO) } \\
-0.073\end{array}$ & $\begin{array}{l}\text { (EURO) } \\
3.881\end{array}$ & $\begin{array}{l}\text { (EURO) } \\
8235\end{array}$ \\
\hline \multicolumn{5}{|l|}{ OVOSTAR } \\
\hline $\begin{array}{l}\text { IV quarter } \\
2013\end{array}$ & $\begin{array}{l}\text { (EURO) } \\
15978\end{array}$ & $\begin{array}{l}\text { (EURO) } \\
2.663\end{array}$ & $\begin{array}{l}\text { EURO) } \\
19.917\end{array}$ & $\begin{array}{l}\text { (EURO) } \\
18451\end{array}$ \\
\hline $\begin{array}{l}\text { II } \quad \text { quarter } \\
2014\end{array}$ & $\begin{array}{l}\text { (EURO) } \\
3322\end{array}$ & $\begin{array}{l}\text { (EURO) } \\
0.553\end{array}$ & $\begin{array}{l}\text { (EURO) } \\
16.667\end{array}$ & $\begin{array}{l}\text { (EURO) } \\
4253\end{array}$ \\
\hline
\end{tabular}

Source: the author on the basis of the financial data of the WIG-Ukraine companies

Price to earnings and price to shares express the value in PLN and it is a value characterized by the results of the companies which affect these values (Parvi R., 2014; Parvi R., 2014). Similarly, price to book value of a company ranges from PLN 0.13 (KSGAGRO) to PLN 1.16 (OVOSTAR). Comparing these values to the maximum values reached by the companies, we should note that the value of PLN 0.80 PLN as maximum (IMCOMPANY) and of PLN 1.16 (OVOSTAR) were values reached by the companies during their quotations on the market over the last few years (2011-2015).

Table 3: Financial ratios of the companies listed on the WIG-UKRAINE as of 04.03.2015

\begin{tabular}{|l|l|l|l|}
\hline Name & C/P & $\begin{array}{l}\text { P/OE (price/ operating } \\
\text { earnings) }\end{array}$ & P/BV PLN \\
\hline COALENERG & 0.19 & -0.92 & -1.50 \\
\hline ASTARTA & 0.39 & 4.10 & 0.59 \\
\hline KERNEL & 0.31 & 2.51 & 0.73 \\
\hline IMCOMPANY & 0.43 & 1.47 & 0.80 \\
\hline KSGAGRO & 0.28 & 3.30 & 0.13 \\
\hline KDMSHIPNG & 0.55 & -4.61 & 0.31 \\
\hline MILKILAND & 0.08 & 1.99 & 0.22 \\
\hline OVOSTAR & 1.68 & 3.85 & 1.16 \\
\hline
\end{tabular}

Source: by the author on the basis of the financial data of the WIG-Ukraine companies

In view of the foregoing, we should note that from the above financial data we can calculate fair values of particular companies listed on the WIG-Ukraine.

Table 4: Values of the companies listed on the WIG-UKRAINE as of 04.03.2015

\begin{tabular}{|l|l|l|l|}
\hline Name & Present value & Maximum value & Fair value \\
\hline COALENERG & 0.64 & 28,68 & 22.05 \\
\hline ASTARTA & 25.50 & 102,62 & 93.24 \\
\hline KERNEL & 31.99 & 86,58 & 69.06 \\
\hline IMCOMPANY & 5.90 & 17,36 & 16.22 \\
\hline KSGAGRO & 1.08 & 28,08 & 23.45 \\
\hline KDMSHIPNG & 5.63 & 37,08 & 35.11 \\
\hline MILKILAND & 3.61 & 49,26 & 27.09 \\
\hline OVOSTAR & 69.90 & 130,57 & 121.98 \\
\hline
\end{tabular}

Source: by the author on the basis of the financial data of the WIG-Ukraine companies

From table 4 (2), it can be concluded that the fair value is significantly higher than the current share price of the companies listed on the WIG-Ukraine. A particular "pearl" in the index may be a well prospering OVOSTAR that is largely undervalued.

Table 5: Values of the companies listed on the WIG-UKRAINE as of 04.03 .2015 
Rafal Parvi

School of Banking in Wroclaw

Street Fabryczna 29-31, 53-609 Wroclaw, Poland

\begin{tabular}{|l|l|l|}
\hline Name & $\begin{array}{l}\text { Deviation from the fair value in } \\
\text { PLN }\end{array}$ & Fair value \\
\hline COALENERG & 21.41 & 22.05 \\
\hline ASTARTA & 67.74 & 93.24 \\
\hline KERNEL & 37.07 & 69.06 \\
\hline IMCOMPANY & 10.32 & 16.22 \\
\hline KSGAGRO & 22.37 & 23.45 \\
\hline KDMSHIPNG & 29.48 & 35.11 \\
\hline MILKILAND & 23.48 & 27.09 \\
\hline OVOSTAR & 52.08 & 121.98 \\
\hline
\end{tabular}

Source: by the author on the basis of the financial data of the WIG-Ukraine companies

\section{Conclusion}

The share price of the companies listed on the WIG-Ukraine is largely undervalued by the present financial situation worldwide and even by speculative actions of particular capital groups that "wander around" the world and subsist thanks to speculative actions using only surplus on share purchase and sale and then relocate capital to another place. Such investors are not interested in the business value and in the company's situation, its share price, but only in profit.

We can see clearly that the share price of the companies listed on the WIG-Ukraine differs significantly from the fair value that has been calculated and presented in the paper. In view of the foregoing, we should particularly emphasize that this value should be achieved in the future periods, the proof of which is even growing total value of price to earnings $(\mathrm{P} / \mathrm{E})$ on the WIG-Ukraine index, where its minimal level has been already achieved. The fair value of the WIG-Ukraine companies should be achieved in the period of a few years, namely until 2020, given improved situation on world financial markets. It should be noted that there is no measured at fair value of shares and it is not easy to measure the stock shares showing their fair value.

\section{References}

- $\quad$ Borowski K., (2013) "Wyznaczanie punktów zwrotnych indeksu Wig przy pomocy wybranych metod analizy czasowej". Bossa.pl

- Copeland T., Koller T., Murrin J., (1997). "Wycena: mierzenie i kształtowanie wartości firmy", WIG - Press, Warszawa.

- $\quad$ Frąckowiak W., (1998). "Fuzje i przejęcia przedsiębiorstw", PWE.

- Jajuga K., (1996). Jajuga T. "Inwestycje", Wydawnictwo Naukowe PWN, Warszawa.

- Kufel M., (1992). "Metody wyceny przedsiębiorstw", Wydawnictwo Park, Bielsko Biała.

- Parvi R., (2014). "Analysis of companies of the energy sector based on an example of the companies quoted on the Warsaw Stock Exchange in Poland and their fair value"CER - International Scientific Conference, LONDON 2014. CrossRef

- Parvi R., (2014). "The analysis of companies of the Polish fuel sector based on an example of PKN Orlen and Lotos companies versus walue of fuel prices and their impact on fuel sector management", ESD - International Scientific Conference Economic and Social Development, Zagreb Croatia 2014.

- $\quad$ Parvi R., (2014). "Investment funds and their financial effectiveness", Goce Delchev University Macedonia \& THOMSON Ltd. Slovakia, EDIS - Publishing Institution of the University of Zilina, 2014.

- Parvi R., (2014). "Share price of companies listed on WIG20 and their fair value". EDIS - Publishing Institution of the University of Zilina EIIC - 3 rd Electronic International Interdisciplinary Conference 2014.

- $\quad$ Pierce R., (2004). "Stocks, Options \& Spreads, Infinity Publishing".

- Thompson B., (2008). "Stock Market Superstar", Insomniac Press.

- Veale S., (2001). "Stocks, Bonds, Options, Futures", Prentice Hall Press. 